\title{
ANALISIS PENGEMBANGAN KARIR KARYAWAN PADA PT. BFI FINANCE TbK PEKANBARU
}

\author{
ZAMHARIL YAHYA \& FITRI HIDAYATI
}

Fitrihidayanti_uin@yahoo.co.id

\begin{abstract}
ABSTRAK
Manajemen sumber daya manusia dilaksanakan dalam rangka mengelola personalia yang ada dalam lingkungan suatu organisasi atau perusahaan. Karyawan merupakan faktor utama untuk menjalankan fungsi perusahaan dalam rangka mencapai efisiensi dan efektifitas kerja terutama pada sumber daya manusianya, karena sumber daya manusia memiliki fungsi operasional. Salah satu fungsi yang dimaksud yaitu pada fungsi operasional adalah pengembangan karir.

PT. BFI Finance Tbk Pekanbaru telah melakukan proses pengembangan karir salah satunya dengan memperhatikan faktor latar belakang pendidikan saat masuk kerja dan pendidikan karyawannya kebanyakan telah selesai kuliah pada beberapa perguruan tinggi juga beberapa tamatan SMK/SMA sederajat. Kesempatan-kesempatan untuk maju ini membantu tujuan personalia untuk mengembangkan tenaga-tenaga kerja pengganti intern maupun rencana karir individu, keahlian dan keterampilan baik itu secara teknis, keterampilan berinteraksi secara efektif dengan rekan sekerja dan dengan atasan serta keterampilan memecahkan masalah dalam pekerjaan.

Sedangkan pada faktor pengalaman kerja, pengalaman kerja yang dimiliki oleh karyawan PT. BFI Finance Tbk Pekanbaru berbeda-beda, sehingga hal ini disebabkan setiap pekerja mempunyai pengalaman dari pekerjaan yang berbedabeda yang telah diselesaikan berulang - ulang dalam menempuh perjalanan karirnya. Pengalaman kerja untuk karyawan PT. BFI Finance Tbk Pekanbaru meliputi banyaknya jenis pekerjaan atau jabatan yang pernah diduduki oleh seseorang dan lamanya mereka bekerja pada masing-masing pekerjaan atau jabatan tersebut. Oleh karena itu pengalaman kerja yang didapat karyawan akan meningkatkan kemampuannya dalam melaksanakan pekerjaan dan mengembangkan karir yang telah diraihnya.

Kesesuaian pengembangan karir yang dijalani oleh karyawan berdampak terhadap prestasi karir, sikap karir dan keadaptasian karir karyawan. Kesesuaian disini mencakup kesesuaian atas prestasi kerja berupa imbalan gaji yang meningkat, kesesuai dengan sikap yang positif terhadap begbagai persoalan dalam pekerjaan dan kesesuaian dalam penggunaan aplikasi pengetahuan, keahlian dan teknologi mutakhir yang menjadi tuntutan pekerjaan/ jenjang karir.

Dari penjelasan di atas masih terdapat beberapa kekurangan dari kebijaksanaan-kebijaksanaan yang dilakukan oleh Manajemen Sumber Daya
\end{abstract}


Manusia PT. BFI Finance Tbk Pekanbaru. Untuk itu perlu disarankan agar perusahaan lebih selektif pada tingkat pendidikan dan pengalaman karena semakin tinggi pendidikan dan semakin lama pengalaman kerja seseorang diiringi ilmu pengetahuan baik itu secara teknis maupun secara konseptual maka akan mempengaruhi tingkat kinerja karyawan maupun kinerja perusahaan dan akan berdampak positif terhadap peningkatan karir seseorang dalam perusahaan tersebut.

Kata Kunci : Pengembangan Karir (Prestasi Karir, Sikap Karir, Keadaptasian Karir), Karakteristik Individu (Keahlian, Pendidikan, Pengalaman)

\section{PENDAHULUAN}

Dalam era yang serba kompetitif ini permasalahan yang dihadapi perusahaan akan semakin komplek. Saat ini banyak organisasi melakukan langkah restrukturisasi akibat adanya perubahan kondisi ekonomi. Perubahan-perubahan ini berarti bahwa organisasi-organisasi harus mengetahui bagaimana cara yang paling baik mendayakan karyawan-karyawan pada semua jenjang dalam organisasi. Kunci untuk memenangkan komitmen perusahaan, karyawan-karyawan adalah menawarkan kepada mereka suatu kesempatan untuk memiliki dan mengisi sebuah karir yang berhasil.

Di Indonesia, sumber daya manusia betul-betul menghadapi tantangan dan persaingan yang kompleks. Untuk dapat bersaing di pasar global sangat diperlukan barang dan jasa yang berdaya saing tinggi yaitu barang dan jasa yang memiliki keunggulan-keunggulan mutu tertentu. Untuk menghasilkan barang dan jasa yang berdaya saing tinggi diperlukan tingkat efisiensi yang tinggi. Tingkat efisiensi yang tinggi ditentukan oleh kualitas sumber daya manusia yang tinggi, yaitu sumber daya manusia yang professional dan terampil, yang dapat dibangun dengan cara diantaranya usaha dalam pembentukan watak, disiplin, sportivitas, tanggung jawab serta peningkatan dan pengembangan kualitas diri.

Dalam kaitannya dengan era globalisasi PT. BFI Finance Tbk Pekanbaru hadir sebagai satu perusahaan yang ikut berkompetensi di arena persaingan global. Dengan semakin ketatnya persaingan dunia usaha dan sulitnya mempertahankan kredibilitas perusahaan saat ini.

PT. BFI Finance Tbk Pekanbaru mampu menjawab tantangan tersebut. PT. BFI Finance Tbk Pekanbaru merupakan salah satu perusahaan yang bergerak dibidang pembiayaan alat - alat berat, mobil dan sepeda motor. Manajemen sumber daya manusia dilaksanakan dalam rangka mengelola personalia yang ada dalam lingkungan suatu organisasi atau perusahaan karena karyawan merupakan faktor utama untuk menjalankan fungsi perusahaan dalam rangka mencapai efisiensi dan efektifitas kerja terutama pada sumber daya manusianya, karena sumber daya manusia memiliki fungsi operasional. Salah satu fungsi yang dimaksud yaitu pada fungsi operasional adalah 
pengembangan karir pada PT. BFI Finance Tbk Pekanbaru yang akan penulis jabarkan di landasan teori.

Penulis sangat tertarik meneliti mengenai pengembangan karir pada PT. BFI Finance Tbk Pekanbaru karena pada perusahaan tersebut pengembangan karir berpengaruh terhadap individual karyawan dalam melaksanakan aktivitas dan tanggung jawabnya. Dalam hal pengembangan karir atau masalah lainnya maka masalah manajemen sumber daya manusia harus diperhatikan agar kegiatan dapat berjalan dengan baik dan sesuai dengan yang diharapkan dalam suatu organisasi atau perusahaan sehingga karyawan yang ada dalam organisasi tersebut benarbenar diperhatikan dan merasa dibutuhkan oleh organisasi nya. Dengan demikian karyawan berusaha dengan sepenuhnya melakukan pekerjaan yang ditugaskan kepadanya tanpa adanya konflik yang mungkin timbul antara keinginan individu dan organisasi.

Untuk melihat perkembangan pengembangan karir karyawan terlebih dahulu kita lihat jumlah karyawan menurut jabatan pada tabel di bawah ini :

Tabel 1. Jumlah Karyawan Berdasarkan Tingkatan Pendidikan dan Jenjang Manajemen Pada PT. BFI Finance Tbk Pekanbaru Jabatan Jumlah

\begin{tabular}{|l||c||l||c||}
\hline \multicolumn{1}{|c|}{ TINGKAT } & JUMLAH & \multicolumn{1}{|c|}{ JABATAN } & JUMLAH \\
\hline Master Degree (S2) & & & \\
Bachelor Degree (S1) & - & AVP & 1 Orang \\
Diploma & 40 Orang & Manager & 1 Orang \\
Senior High School (SMA) & 6 Orang & Senior Officer & 1 Orang \\
Junior High School (SMP) & - & Officer & 11 Orang \\
Primary School (SD) & - & Staff & 6 Orang \\
& & Supprot Staff & 46 Orang \\
\hline Jumlah & $\mathbf{6 8}$ Orang & Jumlah & 68 Orang \\
\hline \hline
\end{tabular}

Sumber : PT. BFI Finance Tbk Pekanbaru

Kinerja sumber daya manusia PT. BFI Finance Tbk Pekanbaru saat ini sudah sesuai dengan yang diharapkan oleh perusahaan, karena dalam upaya peningkatan sumber daya manusia yang lebih produktif kedepannya, perusahaan memberikan jaminan sosial kepada karyawan sehingga karyawan mendapatkan rasa aman dan biasa menjalankan pekerjaannya dengan professional.

Jadi jelaslah dalam hal ini setiap organisasi memerlukan aktifitas manajemen sumber daya manusia yang baik karena merupakan salah satu faktor yang penting. Maju mundurnya suatu organisasi tergantung pada pelaksanaan tugas dan pengelolaan 
yang baik pada manajemen sumber daya manusia.

Berdasarkan dari uraian tersebut penulis tertarik ingin meneliti dan mengevaluasi mengenai analisis pengembangan karir karyawan pada PT. BFI Finance Tbk Pekanbaru.

\section{Perumusan Masalah}

Berdasarkan latar belakang masalah di atas, maka rumusan masalah penelitian ini adalah :

1. Bagaimana pengembangan karir karyawan pada PT. BFI Finance Tbk Pekanbaru?

2. Bagaimana prestasi karir, sikap karir, dan keadaptasian karir karyawan pada PT. BFI Finance Tbk Pekanbaru?

3. Bagaimana karakteristik individu, keahlian, pendidikan, pengalaman kerja karyawan pada PT. BFI Finance Tbk Pekanbaru?

\section{Tujuan Penelitian}

Berdasarkan perumusan masalah penelitian yang telah diuraikan di atas, maka penelitian ini bertujuan untuk mengetahui :

1. Pengembangan karir karyawan pada PT. BFI Finance Tbk Pekanbaru.

2. Prestasi karir, sikap karir, dan keadaptasian karir karyawan pada PT. BFI Finance Tbk Pekanbaru.

3. Karakteristik individu, keahlian dan pendidikan serta pengalaman kerja karyawan pada PT. BFI Finance Tbk Pekanbaru.

\section{Kegunaan Penelitian}

1. Dapat memperkaya kajian-kajian khususnya tentang manajemen sumber daya manusia terutama pada pengembangan karir karyawan.

2. Dapat digunakan sebagai pertimbangan bagi perusahaan dalam melakukan kebijakankebijakan atas pengembangan karir karyawannya.

3. Diharapkan juga dapat menjadi bahan pertimbangan bagi peneliti selanjutnya terutama yang terkait dengan manajemen sumber daya manusia.

\section{TINJAUAN PUSTAKA}

\section{Pengertian Manajemen Sumber Daya Manusia}

Dalam suatu perusahaan manusia merupakan sumber daya yang penting untuk mencapai keberhasilan dalam menjalankan semua aktifitas perusahaan. Walaupun ditunjang dengan aspek teknologi yang sempurna, tetapi apabila tanpa aspek manusia sulit kiranya perusahaan mencapai tujuannya dengan baik.

Pentingnya sumber daya manusia juga terlihat dari aktifitas perusahaan dalam mencapai tujuan dengan menggunakan sumber daya yang lain seperti uang, bahan baku, metode dan sebagainya baru bisa terlaksana jika ada unsur manusia yang mampu mengelola atau menggunakannya secara maksimal. Hal ini dikarenakan peranan manusia sebagai sumber daya dalam organisasi semakin diyakini kepentingannya, maka semakin mendorong perkembangan ilmu tentang bagaimana mendayagunakan sumber daya manusia tersebut agar mencapai kondisi yang optimal. 
Berbagai pendekatan manajemen dilakukan dalam mengelola sumber daya manusia tersebut, yang berkembang mengikuti perkembangan dari falsafah manajemen yang sedang dikembangkan pada masa itu. Manajemen sumber daya manusia menurut Bambang Wahyudi (2002:1) : "Ilmu dan seni atau proses memperoleh, memajukan atau mengembangkan, dan memelihara sumber daya manusia yang kompeten sedemikian rupa, sehingga tujuan organisasi dapat tercapai dengan efisiensi dan ada kepuasan pada diri pribadi-pribadi yang bersangkutan".

Definisi lain menurut Edwin B Flippo dalam buku Bambang Wahyudi Manajemen Sumber daya Manusia (2002:9) : "Personnel management is the planning, organizing, directing and controlling of the procurement, development, competition, integration,maintenance, and separation of human resources to the end that individual, organizational, and societal objectives are accomplished" Artinya : "manajemen sumber daya manusia merupakan perencanaan,pengorganisasian,penga rahan dan pengawasan daripada pengembangan,pemberian balas jasa, pengintegrasian, pemeliharaan, dan pemisahansumber daya manusia ke suatu titik akhir dimana tujuantujuanperorangan, organisasi dan masyarakat."

Selanjutnya menurut Malayu S.P Hasibuan (2002:10) : "Manajemen sumber daya manusia adalah ilmu dan seni mengatur hubungan dan peranan tenaga kerja agar efektif dan efisien membantuterwujudnya tujuan perusahaan, karyawan dan masyarakat"

\section{Ruang Lingkup Manajemen} Sumber Daya Manusia

Sesuai dengan pengertian manajemen sumber daya manusia yang telah dirumuskan di atas, maka kegiatan-kegiatan pengelolaan sumber daya manusia didalam suatu organisasi dapat diklasifikasikan ke dalam beberapa fungsi. Sebagai ilmu terapan dari ilmu manajemen, maka manajemen sumber daya manusia memiliki fungsi-fungsi pokok yang sama dengan fungsi manajemen dengan penerapan di bidang sumber daya manusia sebagai berikut :

1. Fungsi Perencanaan

2. Fungsi Pengorganisasian

3. Fungsi Pengarahan

4. Fungsi Pengendalian

Di samping fungsi-fungsi pokok, manajemen sumber daya manusia juga memiliki beberapa fungsi -fungsi operasional, diantaranya :

a. Fungsi Pengadaan

b. Fungsi Kedisiplinan

c. Fungsi Pemberhentian

Berkaitan dengan fungsi operasional di atas, maka rotasi pegawai merupakan bagian dari fungsi pengembangan dari manajemen sumber daya manusia.

\section{Peran Manajemen Sumber Daya Manusia}

Manajemen sumber daya manusia mengatur dan menetapkan programkepegawaian yang mencakup masalah-masalah sebagai berikut :

1. Menetapkan jumlah, kualitas, dan penempatan tenaga kerja yang efektif sesuai dengan kebutuhan perusahaan berdasarkan deskripsi pekerjaan, 
spesifikasi jabatan, persyaratan

pekerjaan, dan evaluasi pekerjaan.

2. Menetapkan penarikan, seleksi dan penempatan karyawan berdasarkan azas the right man in the right place and the right man in the right job.

3. Menetapkan program kesejahteraan, pengembangan, promosi, dan pemberhentian.

4. Meramalkan penawaran dan permintaan sumber daya manusia pada masa yang akan datang.

5. Memperkirakan keadaan perekonomian pada umumnya dan perkembangan perusahaan pada khususnya.

6. Memonitor dengan cermat undang-undang perburuhan dan kebijaksanaan pemberian balas jasa perusahaan-perusahaan sejenis.

7. Memonitor kemajuan Teknik Dan Perkembangan Serikat Buruh.

8. Melaksanakan Pendidikan, Pelatihan Dan Penilaian Prestasi Karyawan.

9. Mengatur mutasi karyawan baik vertikal maupun horizontal.

10. Mengatur pemberhentian

pensiun, pesangonnya.

Peranan manajemen sumber daya manusia diakui sangat menentukan bagi terwujudnya tujuan, tetapi untuk memimpin unsur manusia ini sangat sulit dan rumit. Tenaga kerja manusia selain mampu, cakap, dan terampil, juga tidak kalah pentingnya kemauan dan kesungguhan mereka untuk bekerja efektif dan efisien.

\section{Pengembangan Karir \\ Pengertian Karir}

Karir adalah perjalanan yang dilalui seseorang selama hidupnya. Menurut Handoko (2000 : 123), karir adalah semua pekerjaan atau jabatan yang ditangani atau dipegang selama kehidupan kerja seseorang. Dengan demikian karir menunjukkan perkembangan para pegawai secara individual dalam jenjang jabatan atau kepangkatan yang dapat dicapai selama masa kerja dalam suatu organisasi.

Terdapat dua cara pendekatan untuk memahami makna karir Irianto (2001:93). Pendekatan pertama memandang karir sebagai pemilikan (a property) dan occupation atau organisasi. Dimana karir dapat dilihat sebagai jalur mobilitas di dalam organisasi yang tunggal. Pendekatan kedua memandang karir sebagai suatu properti atau kualitas individual dan bukan okupsi atau organisasi. Setelah setiap individu mengakumulasikan serangkaian jabatan, posisi, dan pengalaman tertentu pendekatan ini mengakui kemajuan karir yang telah dicapai seseorang.

\section{Pengertian Pengembangan karir}

Dalam praktek pengembangan karir lebih merupakan suatu pelaksanaan rencana karir seperti yang diungkapkan oleh Handoko (2000: 123)bahwa pengembangan karir adalah peningkatan-peningkatan pribadi yang dilakukan seseorang untuk mencapai suatu rencana karir. Menurut Simamora (1995: 392) proses pengembangan karir dalam suatu pendekatan formal yang 
diambil organisasi untuk memastikan bahwa orang-orang dengan kualifikasi dan pengalaman yang tepat tersedia pada saat dibutuhkan. Sehingga pengembangan karir dapat dikatakan suatu kondisi yang menunjukkan adanya peningkatanpeningkatan status seseorang dalam organisasi dalam jalur karir yang telah ditetapkan dalam organisasi yang bersangkutan.

Berdasarkan pengertianpengertian di atas, terlihat bahwa pengembangan karir harus dilalui dengan penyusunan prasyarat yang harus dimiliki oleh seorang karyawan guna mendukung peningkatan karirnya. Prasyarat - prasyarat itu sifatnya saling mendukung, dalam arti setiap peningkatan karir seorang karyawan harus melalui beberapa kriteria yang sudah ditentukan seperti prestasi, bobot tugas/kerjaan, adanya lowongan jabatan, efisiensi dan lainnya.

Dalam pelaksanaan tanggung jawab pengembangan karir seharusnya diterima bukan sekedar promosi ke jabatan yang lebih tinggi, tetapi sukses karir yang dimaksudkan seorang karyawan mengalami kemajuan dalam bekerja, berupa perasaan puas dalam setiap jabatan yang dipercayakan oleh organisasi Moekijat (1995: 36)

Di samping itu sukses dalam pengembangan karir yang berarti pegawai mengalami kemajuan dalam bekerja adalah meningkatkan keterampilan sehingga lebih berprestasi. Pengembangan karir berdasarkan Analisa Jabatan:

a. Uraian jabatan kondisi fisik kesehatan, pendidikan, pekerjaan, yang dilaksanakan. b. Spesifikasi jabatan: pendidikan, pengalaman, kemampuan, kualifikasi emosi dan syarat kesehatan.

Kunci program pengembangan karir berdasarkan teori Fiedman danArnold dalam Moekijat (1986: 116)

Pertama, organisasi harus menilai pegawai-pegawai secara berkala sepanjang karir mereka untuk mengetahui kekuatan individu yang dapatdipergunakan dalam pekerjaan lain dalam organisasi dan untuk memperbaiki kelemahan individual yang merintangi jalannya karir.

Kedua, organisasi harus dapat memberikan informasi yang lebih realistik kepada pegawai-pegawainya tidak hanya apabila organisasi itu mengambil keputusan-keputusan mengenai penerimaan pegawai, tetapi juga apabila mengambil keputusan mengenai promosi.

Ketiga, kegiatan-kegiatan perencanaan karir menjadi amat sukses apabila kegiatan itu dikoordinasi dengan kegiatan kegiatan lain dalam manajemen sumber daya manusia - seleksi, latihan, perencanaan sumber daya manusia, dan penilaian prestasi kerja.

Keempat, pengembangan karir besar sekali kemungkinan berhasil apabila penyelia lini terlibat. Sesuai dengan asas pembinaan yang berdasarkan prestasi kerja pengembangan karir pegawai dilaksanakan melalui kenaikan pangkat dan pengangkatan dalam jabatan. Agar sumber daya manusia di dalam organisasi dapat bekerja dengan efisien dan efektif, sehingga tidak menimbulkan kejenuhan dalam pekerjaan maka diperlukan adanya 
suatu pengembangan karir yang meliputi; mutasi, promosi, demosi.

Menurut Hasibuan (2000: 101), mutasi adalah satu perubahan posisi/jabatan/tempat/pekerjaan yang dilakukan baik secara horizontal maupun vertikal (promosi/demosi) dalam suatu organisasi. Prinsip mutasi adalah memutasikan karyawan kepada posisi yang tepat dan pekerjaan yang sesuai, agar semangat dan produktivitas kerjanya meningkat; yang bertujuan untuk meningkatkan efisiensi dan efektivitas kerja dalam perusahaan.

Mutasi merupakan salah satu tindak lanjut yang dilakukan dari hasil penilaian prestasi kerja. Dengan adanya mutasi diharapkan dapat memberikan uraian pekerjaan, sifat pekerjaan, lingkungan pekerjaan, dan alat - alat kerja yang cocok bagi karyawan bersangkutan sehingga dapat bekerja secara efisien dan efektif pada jabatan itu.

Promosi adalah perpindahan yang memperbesar authority dan responsibility karyawan ke jabatan yang lebih tinggi di dalam suatu organisasi sehingga kewajiban, hak, status, dan penghasilan semakin besar Malayu (2000 :107).

Demosi menurut Hasibuan (2000: 112) adalah perpindahan karyawan dari suatu jabatan ke jabatan yang lebih rendah di dalam satu organisasi, wewenang, tanggung jawab, pendapatan serta statusnya semakin rendah.

Keberhasilan sebuah organisasi ditentukan oleh individu di dalamnya dalam artian kerja disesuaikan tugas.

\section{Unsur-unsur Pokok Program Pengembangan Karir}

Program pengembangan karir yang direncanakan mengandung tiga unsur pokok Moekijat (1995 : 103) :

a. Membantu pegawai dalam menilai kebutuhan karir internnya sendiri.

b. Mengembangkan dan mengumumkan memberitahukan kesempatan-kesempatan karir yang ada dalam organisasi.

c. Menyesuaikan kebutuhan dan kemampuan pegawai dengan kesempatan-kesempatan karir.

Sesuai dengan tiga unsur di atas diharapkan karir karyawan itu merupakan suatu unsur yang sangat penting yang sifatnya pribadi. Oleh karena itu organisasi memberi kebebasan kepada karyawan untuk mengambil keputusan sendiri mengenai tujuan serta kesempatan menjalani karirnya. Unsur karir yang baik adalah adanya penghargaan yang wajar terhadap masa kerja, kesetiaan, pengabdian, pengalaman, sehingga pegawai yang berpengalaman, setia mengabdi kepada negara pemerintah dan tugas kewajibannya akan mendapat penghargaan selayaknya. Selain itu, dalam sistem karir seseorang dapat naik pangkat dan jabatan berdasarkan masa kerja sudah tentu memperhatikan kecakapan, prestasi kerja, kesetiaan dan sebagainya Nainggolan (1994: 151).

Menurut konsep Schein dalam Dubrin (1989:14) faktor yang mempengaruhi pengembangan karir adalah:
a. Manajerial
Competence
(Kemampuan manajerial)
b. Technicalfungsional
(Kemampuan teknis)
c. Security (Keamanan)
d. Creativity (Kreativitas) 
e. Autonomi and Independence

(Otonomi Kebebasan)

Dari kelima konsep tersebut, dalam kemampuan manajerial seseorang mencari dan menghargai kesempatan - kesempatan untuk merencanakan. Hal ini merefleksikan nilai - nilai lebih jauh untuk kompetensi antar pribadi, kompetensi analitis dan kematangan emosional.

Dalam kemampuan teknis, seseorang mencari dan menghargai kesempatan untuk melatih berbagai macam bakat dan bidang - bidang kompetensi teknis. Dengan keamanan, seseorang termotivasi terutama oleh kebutuhan untuk menstabilkan situasi karirnya, sekalipun ia harus berada di bawah komando orang lain atau dia hanya melakukan pekerjaan yang kurang penting dalam organisasi.

Untuk kreatifitas seseorang dikendalikan oleh suatu kebutuhan untuk membangun atau menciptakan sesuatu yang keseluruhannya merupakan usahanya. Autonomy and independence, seseorang mencari situasi bekerja dimana dia akan memperoleh kebebasan dari aturan aturan organisasi untuk menunjukkan kompetensi professional teknis.

Selanjutnya Gibson (1992: 208), mengemukakan ada empat karakteristik dalam penilaian individu berkenaan dengan kesesuaian karir mereka dengan harapan mereka yaitu:

1. Prestasi karir

2. Sikap karir

3. Keadaptasian karir

4. Identitas karir

Dalam prestasi karir, gaji dan posisi merupakan indikator yang lebih popular tentang prestasi karir (career performance). Khususnya semakin cepat kenaikan gaji seseorang dan semakin menapak jenjang hierarki semakin tinggi pula prestasi karyawan.

Sikap karir (career altitude) mengacu pada seseorang memandang dan menilai karir mereka. Orang yang mempunyai sikap karir positif juga akan mempunyai persepsi dan penilaian yang positif atas karir mereka. Sikap karir positif lebih mungkin sesuai dengan tuntutan karir dan peluang yang konsisten dengan kepentingan, nilai- nilai kebutuhan dan kemampuan individu.

Profesi selalu berubah, yang menuntut adanya pengetahuan dan keahlian baru untuk mempraktekkan. Orang yang tidak dapat beradaptasi dengan perubahan di atas akan menerimanya dalam praktek karir mereka, dan menghadapi resiko ketinggalan zaman.

Keadaptasian karir menunjukkan aplikasi pengetahuan, keahlian dan teknologi mutakhir dalam perjalanan karir.

Identitas karir (career identity) terdiri dari dua komponen utama:

1. Sejauh mana orang - orang memiliki kesadaran yang konsisten tentang kepentingan, nilai dan harapan mereka bagi masa depan.

2. Sejauh mana orang - orang memandang hidup mereka konsisten sepanjang waktu, sejauh mana mereka melihat diri sendiri sebagai masa lalu mereka. Gagasan yang diutarakan dalam konsep ini adalah "ingin menjadi apa saja,dan apa yang harus saya lakukan untuk dapat menjadi orang yang saya inginkan". 
Untuk mencapai adanya kesesuaian perlu penempatan orang yang tepat pada tempat yang tepat, artinya seorang pegawai ditunjuk menduduki suatu jabatan haruslah mempunyai pangkat yang sesuai untuk jabatan itu. Nainggolan (1994: 124).

Namun untuk dapat melaksanakan prinsip pokok tersebut perlu adanya batasan yang dapat dijadikan sebagai dasar pengangkat. Dengan adanya ukuran yang berlaku, diharapkan terjadi unsur " like or dislike " dalam mengisi jabatan di lingkungannya.

\section{Perencanaan karir}

Beach (1984: 320) menyatakan pengembangan karir terdiri dari dua bagian yaitu perencanaan karir dan manajemen karir. Dimana keduanya dijelaskan dalam gambar 2.1.

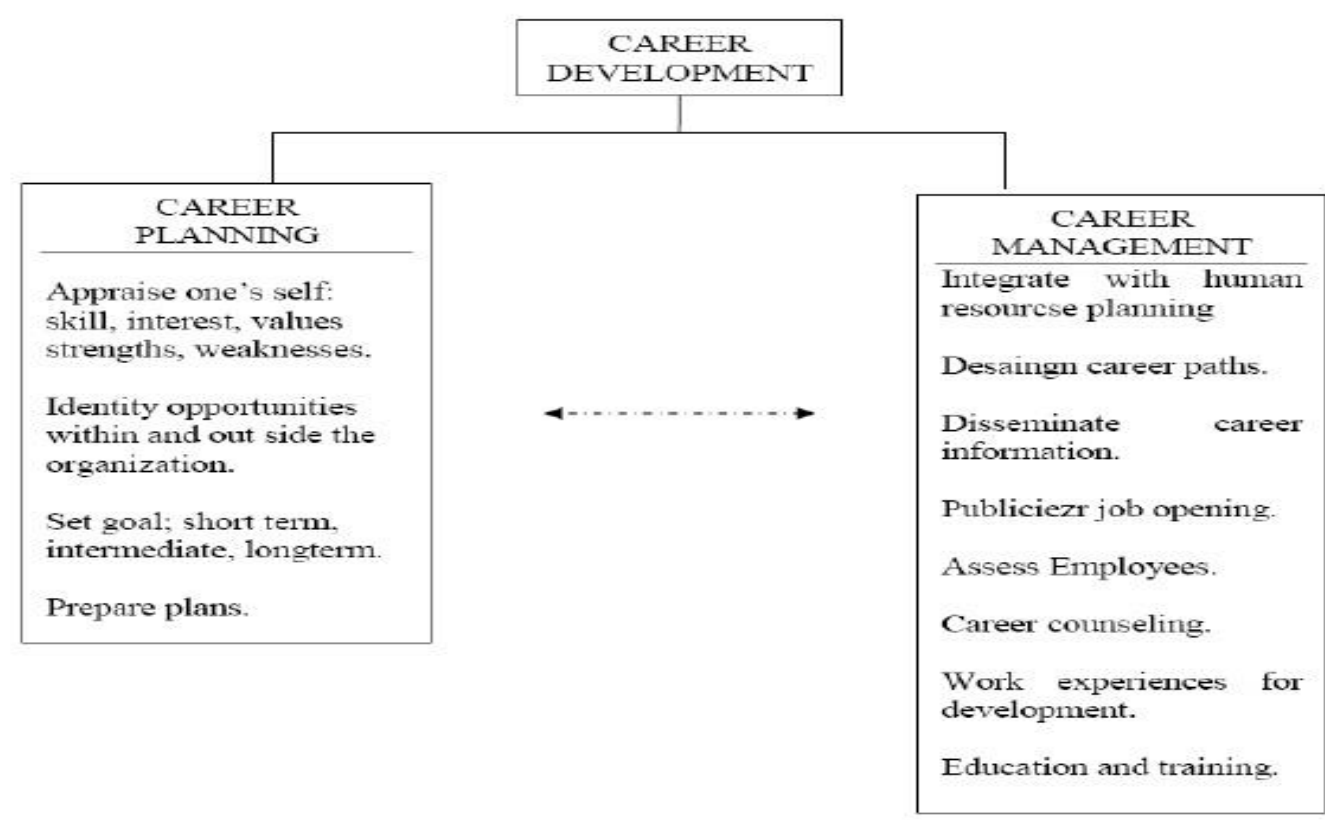

Gambar 2.1. The Contens of Career Planning And Career Management As Components Development. (Beach, 1984: 320)

Untuk mewujudkan manajemen karir bagi diri sendiri diperlukan kesadaran dan pemahaman para pegawai bahwa setiap pekerjaan/jabatan selalu memberikan kesempatan untuk maju dan berkembang. Pegawai juga harus memahami bahwa tanggung jawab pengembangan karir berada pada individu itu sendiri.

Manajemen karir yang ada dalam organisasi akan menjadi suatu kekuatan dalam upaya untuk mendorong individu agar tumbuh dan merealisasikan potensinya secara penuh. Organisasi akan memberikan kesempatan untuk semua individu agar tumbuh dan merealisasikan

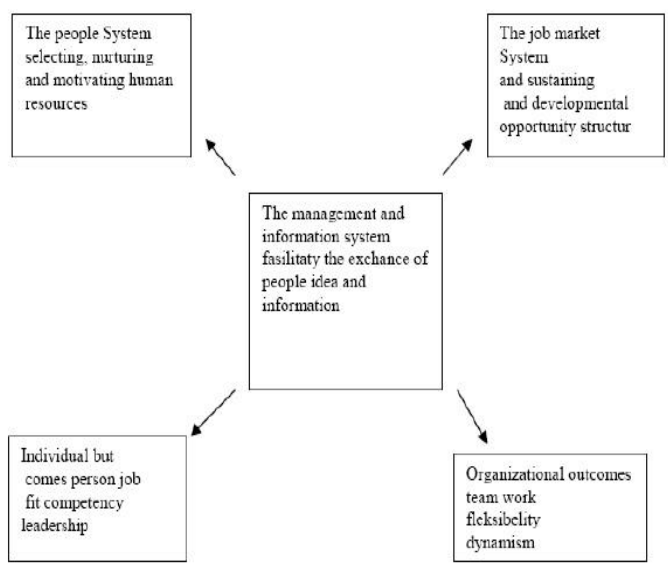

Gambar 2.2. Career Development - A System Views (Pfeffer, 2002: 269) 
potensinya secara penuh serta mengembangkan karirnya. Tujuan manajemen karir akan tercapai apabila menghubungkan sistem mengembangkan karirnya. Tujuan manajemen karir akan tercapai apabila menghubungkan sistem tenaga kerja dan sistem pasar kerja melalui sistem informasi manajemen Permasalahan yang muncul adalah bagaimana mengembangkan karir dalam lingkungan yang begitu dinamis, sehingga meminimalkan ketidaksesuaian penempatan peran, meningkatkan kompetensi dan menempatkan individu dalam posisi kunci.

Menurut Deasler dalam Preffer (2002: 256) Perencanaan dan pengembangan karir adalah proses yang disengaja dimana dengan melalui seseorang menjadi sadar akan atribut -atribut yang berhubungan dengan karir personal dan serangkaian langkah sepanjang hidup yang memberikan sumbangan pada pemenuhan karir. Karir akan mendukung efektivitas individu dan organisasi dalam mencapai tujuan.

Strategi perencanaan karir memungkinkan organisasi mengembangkan dan menempatkan pegawai dalam jabatan - jabatan yang sesuai dengan minat, kebutuhan, dan tujuan karirnya.

\section{Karakteristik Individu}

Organisasi merupakan wadah bagi individu untuk mencapai tujuan, baik tujuan pribadi maupun tujuan organisasi. Individu dengan karakter yang tersendiri dan organisasi yang juga memiliki karakter tertentu yang saling menyesuaikan. Latar belakang individu dapat menjadikan ciri-ciri tertentu pada setiap individu. tenaga kerja dan sistem pasar kerja melalui sisteminformasi manajemen. (terlihat pada gambar 2.2)

Menurut Moekijat (1996: 103) karir seseorang merupakan unsur yang sangat penting yang bersifat pribadi.

Menurut Mathis (2002: 64) ada empat karakteristik individu yang mempengaruhi bagaimana orang-orang membuat pilihan karir :

1. Minat.

2. Jati Diri.

3. Kepribadian.

4. Latar belakang sosial.

Selama bekerja individu
mempunyai konsep, rencana
pengembangan sumber daya manusia
yang merupakan bagian dari
pengembangan karir.

Keahlian

Keahlian mencakup technical skill,human skill, conceptual skill, kecakapan untuk memanfaatkan kesempatan, serta kecermatan penggunaan peralatan yang dimiliki perusahaan dalam mencapai tujuan.

Menurut Ruki (2002: 35), Keahlian yang harus dimiliki seseorang adalah:

1. Keahlian teknis.

2. Keahlian interaksi atau hubungan antar manusia.

3. Keahlian konseptual

\section{Pendidikan}

Pendidikan merupakan faktor penting dalam menentukan kemampuan kerja karyawan. Pendidikan dan pengalaman kerja merupakan langkah awal untuk melihat kemampuan seseorang Handoko (1998 : 80). Menurut Hasibuan (2000:54), pendidikan 


$\begin{array}{lrr}\text { merupakan } & \text { indikator } & \text { yang } \\ \text { mencerminkan } & \text { kemampuan } \\ \text { seseorang } & \text { untuk } & \text { dapat } \\ \text { menyelesaikan } & \text { suatu } & \text { pekerjaan. } \\ \text { Dengan latar belakang } & \text { pendidikan } \\ \text { pula seseorang dianggap akan } \\ \text { mampu menduduki suatu jabatan } \\ \text { tertentu. }\end{array}$

\section{Pengalaman Kerja}

Selain pendidikan formal yang harus dimiliki individu juga perlu memiliki pengalaman kerja, serta mampu beradaptasi dengan lingkungannya dalam organisasi, untuk meniti suatu karir dan mengembangkan potensi dirinya.

Pengalaman kerja yang dimiliki oleh pekerja dalam organisasi yang berbeda-beda, sehingga hal ini disebabkan setiap pekerja mempunyai pengalaman dari pekerjaan yang berbeda-beda yang telah diselesaikan berulang - ulang dalam menempuh perjalanan karirnya.

\section{Kerangka Pemikiran}

Pengembangan

karier

merupakan tanggung jawab suatu organisasi yang menyiapkan karyawan dengan kualifikasi tertentu, agar pada waktu dibutuhkan organisasi sudah memiliki karyawan dengan kualifikasi tertentu. Sifatnya paternalistik, dari atas ke bawah dan tersentralisasi. Pengembangan karir biasanya dipengaruhi oleh dua faktor yaitu faktor karakteristik individu dan karakteristik organisasi. Karakteristik individu mencakup keahlian, pendidikan dan pengalaman. Sedangkan karakteristik organisasi mencakup sumber daya, iklim kerja dan struktur organisasi (Simamora, 1997: 507).

Pengembangan karir akan dinilai sempurna apabila adanya kesesuaian antara karir yang diperoleh dengan hasil penilaian individu berupa kesesuaian prestasi karir, sikap karir yang positif, keadaptasian karir dan identitas karir (Gibson, 1992: 208).

Gambar 1.4

Kerangka Pemikiran Penelitian

\begin{tabular}{|l|l|}
\hline Karakteristik Individu : & Pengembangan karir : \\
1. Pendidikan & $\longrightarrow$ \\
2. Keahlian & 1. Prestasi karir \\
3. Pengalaman & 2. Sikap karir \\
3. Keadaptasian karir
\end{tabular}

Sumber : Data olahan dari Simamora (1997) dan Gibson (1992)

Berdasarkan gambar di atas tersebut dapat dijelaskan bahwa prestasi karir, sikap karir dan keadaptasian karir karyawan merupakan unsur kesesuaian pengembangan karir karyawan dan merupakan hasil dari penilaian individu melalui indikator keahlian, pendidikan dan pengalaman yang dimiliki oleh karyawan.

\section{Hipotesis}


1. Pengembangan karir karyawan pada PT. BFI Finance Tbk Pekanbaru berdasarkan pendidikan terakhir saat masuk bekerja, pendidikan dan pelatihan dalam jabatan, masa kerja karyawan, dan kedudukan dalam jabatan.

2. Prestasi karir, sikap karir dan keadaptasian karir sesuai dengan hasil pengembangan karir karyawan PT. BFI Finance Tbk Pekanbaru

3. Penilaian Karakteristik Individu Karyawan PT. BFI Finance Tbk Pekanbaru berdasarkan keahlian, keterampilan dan pengalaman kerja.

\section{METODOLOGI PENELITIAN}

\section{Objek Penelitian}

Penelitian ini dilaksanakan

pada karyawan PT. BFI Multi Finance Tbk Cabang Pekanbaru. Adapun alasan dipilihnya tempat ini merupakan salah satu perusahaan finance yang paling senior dan dianggap mampu memberikan informasi tentang pengembangan karir karyawan dalam aplikasi manajemen sumber daya manusia.

\section{Teknik Pengumpulan Data}

Sesuai dengan metode penelitian yang digunakan, maka teknik pengumpulan data yang digunakan dalam penelitian adalah sebagai berikut :
a. Library Research (Penelitian Perpustakaan)
b. Field Research (Penelitian Lapangan) Mengumpulkan data yang bersumber dari PT. BFI Multi Finance Tbk Cabang Pekanbaru dengan cara

\begin{abstract}
wawancara yang dilakukan dengan pihak tertentu yang berhubungan dengan pokok masalah untuk memperoleh data-data tentang pengembangan karir karyawan.
\end{abstract}

\begin{abstract}
ANALISIS DATA
Penelitian merupakan proses yang saling berkaitan dan berkesinambungan, penelitian ini dilakukan untuk memperoleh jawaban dari pertanyaan pertanyaan atau gejala - gejala yang menarik perhatian peneliti. Dalam menempuh suatu penelitian diperlukan tahapan - tahapan yang sistematis dimana setiap tahap saling berkaitan, penelitian harus dikerjakan dengan baik dan cermat. Metode yang digunakan dalam penelitian ini adalah metode deskriptif.
\end{abstract}

\section{Pembahasan}

Manajemen sumber daya manusia memiliki beberapa fungsi yang bersifat managerial dan operasional. Fungsi operasional meliputi pengadaan,pengembangan, pemberian kompensasi, pengintegrasian, pemeliharaan, kedisiplinan, dan pemberhentian. Berkaitan dengan fungsi operasional di atas, maka rotasi karyawan merupakan bagian dari fungsi pengembangan dari manajemen sumber daya manusia.

Pengembangan karyawan melalui rotasi karyawan ini merupakan salah satu kegiatan penting dalam melaksanakan,menempatkan, dan mendayagunakan karyawan secara efektif dan efisien. Sebab perusahaan yang mendambakan kemajuan di tengah-tengah persaingan yang ketat 
perlu memiliki karyawan yang berkualitas dan mampu melakukan tugas-tugasnya dengan baik.

$$
\text { Untuk meningkatkan }
$$

semangat dan kualitas karyawan yang tinggi, sudah seharusnya pihak perusahaan mengadakan rotasi karyawan dalam upaya meningkatkan semangat kerja karyawannya tersebut.

Pembahasan mengenai analisis pengembangan karir karyawan pada PT. BFI Finance Tbk Pekanbaru dapat diuraikan sebagai berikut :

\section{Pengembangan Karir Karyawan Pada PT. BFI Finance Tbk Pekanbaru}

Pengembangan karir yang dilaksanakan dan dikembangkan di PT. BFI Finance Tbk Pekanbaru melalui pembinaan karir dan penilaian sistem prestasi kerja dan sistem karir pada umumnya melalui kenaikan pangkat, mutasi jabatan serta pengangkatan dalam jabatan.

Oleh sebab itu setiap karyawan dalam meniti karirnya, diperlukan adanya perencanaan karir untuk menggunakan kesempatan karir yang ada. Terlihat bahwa pengembangan karir harus dilalui dengan penyusunan prasyarat yang harus dimiliki oleh seorang karyawan guna mendukung peningkatan karirnya. Prasyarat- prasyarat itu sifatnya saling mendukung, dalam arti setiap peningkatan karir seorang karyawan harus melalui beberapa kriteria yang sudah ditentukan seperti prestasi, bobot tugas/ kerjaan, adanya lowongan jabatan, efisiensi dan lainnya. Karyawan PT. BFI Finance Tbk Pekanbaru yang sukses dalam pengembangan karir berarti karyawan mengalami kemajuan dalam bekerja dimana karyawan dapat meningkatkan keterampilan sehingga lebih berprestasi dan pada perusahaan ini diberikan kesempatan untuk :

1. Kesempatan untuk mencapai sesuatu yang berharga.

2. Kesempatan untuk mengembangkan kecakapan kemampuan, pengembangan karir karyawan PT. BFI Finance Tbk Pekanbaru berdasarkan :

a. Pendidikan terakhir karyawan saat masuk ke PT. BFI Finance Tbk Pekanbaru.

b. Pendidikan dan pelatihan dalam jabatan, karyawan dapat mengembangkan

kemampuannya dengan

langsung mempraktekkan di lapangan kerja.

c. Masa kerja karyawan, masa kerja berkisar dalam tahunan seperti ; 0 - 5 tahun, 6-10 tahun, 11 - 20 tahun.

d. Jabatan meliputi item: Kedudukan yang menunjukkan tugas, tanggung jawab, wewenang hak seorang karyawan.

Sementara jika dikaitkan dengan kunci pengembangan karir berdasarkan teori Fiedman dan Arnold (dalam Moekijat, 1986: 116) yang dijalankan oleh PT. BFI Finance Tbk Pekanbaru adalah

1. Organisasi harus menilai karyawan -karyawan secara berkala sepanjang karir mereka untuk mengetahui kekuatan individu yang dapat dipergunakan dalam pekerjaan lain dalam organisasi dan untuk memperbaiki kelemahan individual yang merintangi jalannya karir. 
2. Kegiatan-kegiatan perencanaan karir menjadi amat sukses apabila kegiatan itu dikoordinasi dengan kegiatan - kegiatan lain dalam manajemen sumber daya manusia - seleksi, latihan, perencanaan sumber daya manusia, dan penilaian prestasi kerja.

Sesuai dengan asas pembinaan yang berdasarkan prestasi kerja pengembangan karir karyawan pada pada PT. BFI Finance Tbk Pekanbaru dilaksanakan melalui kenaikan pangkat dan pengangkatan dalam jabatan.

Memberi kebebasan kepada karyawan untuk mengambil keputusan sendiri mengenai tujuan serta kesempatan menjalani karirnya adalah hal yang dilaksanakan perusahaan kepada karyawannya. Dalam sistem, karir seorang karyawan pada PT. BFI Finance Tbk Pekanbaru dapat dipromosikan berdasarkan masa kerja yang mempertimbangkan kecakapan, prestasi kerja, kesetiaan.

Faktor -faktor yang

dipertimbangkan karyawan dalam menentukan jalur karir, tujuan karir dan pengembangan karir pada PT. BFI Finance Tbk Pekanbaru :

1. Perlakuan yang adil dalam berkarir. Perlakuan yang adil ini hanya bisa diwujudkan apabila kriteria promosi didasarkan pada pertimbangan-pertimbangan yang obyektif, rasional dan diketahui secara luas dikalangan karyawan.

2. Kepedulian para atasan langsung. Para karyawan pada umumnya mendambakan keterlibatan langsung dalam perencanaan karir masing-masing, salah satu bentuk kepedulian itu adalah memberikan umpan balik kepada para karyawan tentang pelaksanaan tugas masing-masing sehingga para karyawan tersebut mengetahui potensi yang perlu dikembangkan dan kelemahan yang perlu diatasi.

3. Informasi tentang berbagai peluang promosi. Para karyawan pada umumnya mengharapkan bahwa mereka mempunyai akses terhadap informasi tentang berbagai peluang untuk dipromosikan. Akses ini sangat penting terutama apabila lowongan yang tersedia diisi melalui proses seleksi internal yang sifatnya kompetitif.

Sementara faktor yang mempengaruhi pengembangan karir pada PT. BFI Finance Tbk Pekanbaru adalah:
a. Manajerial
Competence

(Kemampuan manajerial)

b. Technical/fungsional Competence (Kemampuan teknis)

c. Creativity (Kreativitas)

Dalam

kemampuan manajerial seseorang mencari dan menghargai kesempatan kesempatan untuk merencanakan. Hal ini merefleksikan nilai - nilai lebih jauh untuk kompetensi antar pribadi, kompetensi analitis dan kematangan emosional. Dalam kemampuan teknis, seseorang mencari dan menghargai kesempatan untuk melatih berbagai macam bakat dan bidang - bidang kompetensi teknis. Untuk kreatifitas seseorang dikendalikan oleh suatu kebutuhan untuk membangun atau menciptakan sesuatu yang keseluruhannya merupakan usahanya. Autonomy and independence, seseorang mencari 
situasi bekerja dimana dia akan memperoleh kebebasan dari aturan aturan organisasi untuk menunjukkan kompetensi professional teknis.

Faktor yang terkait dengan karir yang dilaksanakan pada PT. BFI Finance Tbk Pekanbaru adalah

a. Keadilan dalam karir,

b. Kesadaran tentang kesempatan,

c. Kepuasan karir.

Prestasi Karir, Sikap Karir, dan Keadaptasian Karir Karyawan Pada PT. BFI Finance Tbk Pekanbaru

Dalam prestasi karir, gaji dan posisi merupakan indikator yang lebih popular tentang prestasi karir (career performance). Khususnya semakin cepat kenaikan gaji seseorang dan semakin menapak jenjang hierarki, semakin tinggi pula prestasi karyawan, sedangkan sikap karir (career altitude) mengacu pada seseorang memandang dan menilai karir mereka. Orang yang mempunyai sikap karir positif juga akan mempunyai persepsi dan penilaian yang positif atas karir mereka.

Sikap karir positiflah yang dijalankan PT. BFI Finance Tbk Pekanbaru sehingga akhirnya lebih mungkin sesuai dengan tuntutan karir dan peluang yang konsisten dengan kepentingan, nilai- nilai kebutuhan dan kemampuan individu. Bahkan Profesi selalu berubah, yang menuntut adanya pengetahuan dan keahlian baru untuk mempraktekkannya. Orang yang tidak dapat beradaptasi dengan perubahan di atas akan menerimanya dalam praktek karir mereka, dan menghadapi resiko ketinggalan zaman.

Keadaptasian karir karyawan PT. BFI Finance Tbk Pekanbaru menunjukkan aplikasi pengetahuan, keahlian dan teknologi mutakhir dalam perjalanan karir dan ini pulalah yang dilakukan PT. BFI Finance Tbk Pekanbaru terhadap karyawannya. Sementara untuk identitas karir, PT. BFI Finance Tbk Pekanbaru melihat dari segi :

a. Sejauh mana orang - orang memiliki kesadaran yang konsisten tentang kepentingan, nilai dan harapan mereka bagi masa depan.

b. Sejauh mana orang - orang memandang hidup mereka konsisten sepanjang waktu, sejauh mana mereka melihat diri sendiri sebagai masa lalu mereka. Gagasan yang diutarakan dalam konsep ini adalah "ingin menjadi apa saja, dan apa yang harus saya lakukan untuk dapat menjadi orang yang saya inginkan".

Hal - hal yang perlu dirumuskan dalam mempertimbangkan karyawan untuk menduduki jabatan pada PT. BFI Finance Tbk Pekanbaru sebagai berikut :

1. Penilaian pelaksanaan pekerjaan, yaitu suatu penilaian dalam jangka waktu tertentu yang dapat menggambarkan tentang kesetiaan, prestasi kerja, tanggung jawab, ketaatan, kejujuran, kerjasama, prakarsa dan kepemimpinan seseorang.

2. Keahlian, dimana penempatan seorang 


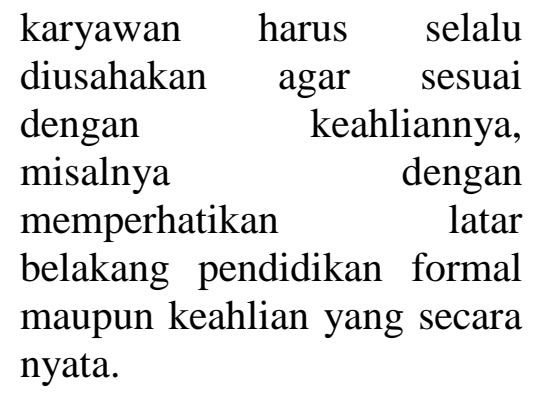

3. Kesetiaan, adalah merupakan unsur penting dalam mempertimbangkan pengangkatan dalam jabatan.

4. Dapat dipercaya, yaitu kepercayaan bahwa ia akan melaksanakan tugasnya dengan baik dan tidak akan menyalahgunakan jabatan untuk kepentingan pribadi, seseorang atau golongan. Dan syarat - syarat lainnya, misalnya pengalaman, kemungkinan, pengembangan dan lainnya.

\section{Karakteristik Individu, Keahlian Dan Pendidikan Serta Pengalaman Kerja Karyawan Pada PT. BFI Finance Tbk Pekanbaru.}

Masa depan seorang individu pada PT. BFI Finance Tbk Pekanbaru tidak tergantung pada kinerja saja. Manajer juga menggunakan ukuran subyektif yang bersifat pertimbangan. Apa yang dipersepsikan oleh penilai sebagai karakter/ prilaku karyawan yang baik dan buruk akan mempengaruhi penilaian.

Berkaitan dengan karakteristik individu, bahwa individu membawa kedalam tatanan organisasi kemampuan, kepercayaan, pribadi, dan penghargaan kebutuhan dan pengalaman masa lainnya. Sehingga karyawan pada PT. BFI Finance Tbk Pekanbaru dilihat berdasarkan : jenis kelamin, status perkawinan,usia, pendidikan, pendapatan keluarga, dan masa jabatan.

Sementara untuk karakteristik individu karyawan PT. BFI Finance Tbk Pekanbaru membuat pilihan karir atas dasar :

a. Minat, karyawan cenderung mengejar karir yang mereka yakini cocok dengan minat mereka.

b. Jati Diri, karir merupakan perpanjangan dari jati diri seseorang juga hal yang membentuk jati diri.

c. Kepribadian, faktor ini mencakup orientasi pribadi karyawan (sebagai contoh karyawan bersifat realistis, menyenangkan dan artistik) dan kebutuhan individual, latihan, kekuasaan dan kebutuhan prestis.

Dalam pengembangan karir karyawan ada persaingan yang sehat yang terjadi, sehingga membutuhkan keahlian merencanakan karir, pendidikan dan pengalaman. Sehingga karakteritik individu dalam penelitian ini dilihat dari keahlian, pendidikan, pengalaman kerja.

\section{Keahlian}

Faktor yang mempengaruhi kemampuan karyawan PT. BFI Finance Tbk Pekanbaru adalah faktor pengetahuan dan keterampilan. Secara psikologis, kemampuan karyawan terdiri dari kemampuan potensi dan kemampuan reality. Keahlian yang dimiliki karyawan PT. BFI Finance Tbk Pekanbaru adalah:

1. Keahlian teknis adalah keahlian dalam pokok pekerjaannya serta kemampuan menerapkan teknik 
dan prosedur mengenai bidang kegiatan tertentu.

2. Keahlian interaksi atau hubungan antar manusia adalah keahlian untuk bekerjasama dengan orang lain, memahami pikirandan perasaan orang lain, serta mampu merangsang dan mendorong oranglain, termasuk anak buah dan rekan kerja.

Keterampilan yang dimiliki karyawan PT. BFI Finance Tbk Pekanbaru :

a. Keterampilan teknis, kebanyakan diarahkan untuk menata dan memperbaiki keterampilan teknis karyawan dimana pekerjaan berubah akibat teknologi dan metode baru yang diperbaiki.

b. Keterampilan antar pribadi, hampir semua karyawan termasuk dalam urut kerja. Kerja karyawan tergantung pada kemampuan karyawan tersebut untuk berinteraksi secara efektif dengan rekan kerja dan atasan.

c. Keterampilan dalam pemecahan masalah, para karyawan harus mampu memecahkan masalah dalam pekerjaannya. Ini mencakup kegiatan mempertajam logika, sebab akibat, mengembangkan alternatif, menganalisa alternatif, dan memilih pemecahan.

Ragam keterampilan merupakan suatu tingkat dalam pekerjaan yang mengharuskan para karyawan melaksanakan kegiatan yang menuntut berbagai keterampilan dan kemampuan PT. BFI Finance Tbk Pekanbaru tidak hanya membutuhkan satu keterampilan tetapi membutuhkan berbagai keterampilan yang akan menguntungkan individu, karena dengan banyaknya keterampilan yang dimiliki seorang karyawan makan akan memudahkan karyawan untuk bisa menguasai banyak bidang pekerjaan yang jika dikerjakan dengan tekun tidak menutup kemungkinan berprestasi di bidang bidang tersebut. Di sisi lain organisasi akan merasa beruntung karena memiliki karyawan yang terampil sehingga memungkinkan mereka akan mengalami pertimbangan promosi.

Karyawan PT. BFI Finance Tbk Pekanbaru lebih cenderung menyukai pekerjaan yang memberi mereka kesempatan untuk menggunakan keterampilan dan kemampuan mereka dibanding dengan pekerjaan yang kurang menantang dan menciptakan kebosanan.

\section{Pendidikan}

Pendidikan merupakan faktor penting dalam menentukan kemampuan kerja karyawan pada PT. BFI Finance Tbk Pekanbaru. Dengan latar belakang pendidikan pula seseorang dianggap akan mampu menduduki suatu jabatan tertentu.Dalam kaitannya dengan pengembangan karir pendidikan yang memadai dan sesuai akan memungkinkan pekerja dapat mengembangkan kemampuannya untuk mencapai tujuan pribadi dan juga akan menjadi perimbangan untuk pengembangan karir. Dimana pada perusahaan ini pendidikan karyawannya kebanyakan yang telah selesai kuliah pada beberapa perguruan tinggi juga beberapa tamatan SMK sederajat. Kesempatan-kesempatan untuk maju ini membantu tujuan personalia 
untuk mengembangkan tenagatenaga kerja pengganti intern maupun rencana karir individu. Dengan pendidikan karyawan mempunyai kesiapan untuk mengetahui adanya peluang dan bagaimana peluang itu dapat direbut tidak dimiliki oleh setiap orang. Atas perbedaan ini, maka ada orang yang berhasil dan tidak berhasil dalam karirnya, meskipun ia mempunyai tingkat dan jenjang pendidikan yang sama.

\section{Pengalaman Kerja}

Pengalaman kerja yang dimiliki oleh pekerja dalam PT. BFI Finance Tbk Pekanbaru berbedabeda, sehingga hal ini disebabkan setiap pekerja mempunyai pengalaman dari pekerjaan yang berbeda-beda yang telah diselesaikan berulang - ulang dalam menempuh perjalanan karirnya.

Pengalaman kerja untuk karyawan PT. BFI Finance Tbk Pekanbaru meliputi banyaknya jenis pekerjaan atau jabatan yang pernah diduduki oleh seseorang dan lamanya mereka bekerja pada masing-masing pekerjaan atau jabatan tersebut. Oleh karena itu pengalaman kerja yang didapat seseorang akan meningkatkan kemampuannya dalam melaksanakan pekerjaan.

\section{KESIMPULAN}

Berdasarkan pada uraianuraian pada masing-masing bab diatas maka dapat diambil kesimpulan sebagai berikut :

1. Pengembangan karir karyawan pada PT. BFI Finance Tbk Pekanbaru berdasarkan latar belakang pendidikan, pendidikan dan pelatihan dalam jabatan, dan masa kerja karyawan.

2. Faktor yang mempengaruhi pengembangan karir pada PT PT. BFI Finance Tbk Pekanbaru adalah Manajerial Competence (kemampuan manajerial), Technicalfungsional Competence (kemampuan teknis), Creativity (kreativitas).

3. Jenjang karir bisa dilalui oleh karyawan ketika karyawan tersebut memiliki prestasi kerja yang tinggi yang ditandai dengan adanya peningkatan gaji. Sikap karir yang positif dijalankan PT. BFI Finance Tbk Pekanbaru sehingga lebih sesuai dengan tuntutan karir dan peluang karir yang konsisten dengan kepentingan, nilai- nilai kebutuhan dan kemampuan individu.

4. Keadaptasian karir karyawan PT. BFI Finance Tbk Pekanbaru menunjukkan aplikasi pengetahuan, keahlian dan teknologi mutakhir dalam perjalanan karir.

5. Untuk karakteristik individu karyawan PT PT. BFI Finance Tbk Pekanbaru membuat pilihan karir atas dasar : Minat, Jati Diri, Kepribadian,

\section{SARAN}

Berikut ini penulis akan
memberikan saran tentang pengembangan karir karyawan pada PT. BFI Finance Tbk Pekanbaru :

1. Dalam rangka pengembangan karir karyawan, sebaiknya PT. BFI Finance Tbk Pekanbaru lebih memperhatikan kunci program pengembangan karir karena masih 
ada beberapa yang masih belum dijalankan.

2. Dalam rangka pengembangan karir karyawan diharapkan PT. BFI Finance Tbk Pekanbaru memperhatikan 2 faktor pengembangan karir lainnya berupa Securiy (Keamanan), dan Autonomi and Independence (Otonomi Kebebasan).

3. Dalam menentukan preastasi karir, dan keadaptasian karir karyawan hendaklah dilakukan secermat mungkin sehingga tidak ada karyawan yang merasa dirugikan.

4. Diharapkan PT. BFI Finance Tbk Pekanbaru dapat tanggap atas alasan yang mempengaruhi bagaimana karyawannya membuat pilihan karir, lebih selektif terhadap pendidikan karyawannya dan pengalaman kerja sehingga PT. BFI Finance Tbk Pekanbaru benar-benar memperkerjakan karyawan yang memiliki prestasi karir yang bagus.

\section{DAFTAR PUSTAKA}

Beach dale 1984 personal fourt edition, collier mc Milan

Dubrin, Andrew J., R. Duanne Ireland, and J. Clifton Williams, 1989. Management and Organization, South Western Publishing Co.,Cincinnati, West Chicago.

Flippo, EB., 1995. Manajemen Personalia. Terjemahan, Ed 6, Jakarta: PenerbitErlangga.

Gibson. (1992). Organisasi dan Manajemen : Perilaku, Struktur dan Proses. Jakarta : Erlangga.
Handoko, Hani T (1998). Manajemen Personalia dan Sumber Daya Manusi ,Edisi ke-2, BFPE, Yogyakarta (1999), Manajemen, Edisi Ke-2, BPFE, Yogyakarta , (2000). Manajemen Personalia dan Sumber Daya Manusia, Edisi keempat, Penerbit : BPFE Yogyakarta

Irianto, J., (2001), Tema-Tema Pokok Manajemen Sumber Daya Manusia, Surabaya, Insan Cendekia.

Malayu Hasibuan, SP. 2000. Manajemen Sumber Daya Manusia, Jakarta: PT.Bumi Aksara

2002. Manajemen dasar Pengertian dan masalah Gaji,Masangung, Bandung.

Mathis R.L dan Jackson J.H, 2002, Manajemen Sumber daya Manusia, Salemba Empat, Jakarta.

Moekijat, dan Harold Koon, Administrasi Manajemen Kantor, Alumni Bandung ,1986, halaman 6.

Moekijat, (1995), Perencanaan dan Pengembangan Karir Pegawai, Cetakan 3,Remaja Rodaskarya, Bandung

Nainggolan, English (1994), Pembinaan Kepegawaian Di Indonesia, PT.Internusa, Jakarta

Moh. Nazir, 2003. Metode Penelitian, Jakarta: Ghalia Indonesia.

Ruki, Achmad S (2002), Sukses Sebagai Manajer Profesional Tanpa Gelar MM Atau MBA, PT Gramedia Pustaka Utama, Jakarta. 
Simamora , Henry, 1995, Manajemen Sumber Daya Manusia, Yogyakarta : P.STIE YPKN

.1997, Manajemen Sumber

Daya Manusia,

Yogyakarta:Bagian Penerbitan STIE YKPN.

Wahyudi, Bambang,

2002, Manajemen Sumber Daya

Manusia, edisi Revisi,Bandung:

Sulita 